\title{
The life cycle cost of a building from the point of view of environmental criteria of selecting the most beneficial offer in the area of competitive tendering
}

\author{
Beata Grzyl ${ }^{1, *}$, Emilia Miszewska-Urbańska ${ }^{1}$, and Magdalena Apollo ${ }^{1}$ \\ ${ }^{1}$ Faculty of Civil and Environmental Engineering, Gdansk University of Technology (GUT), \\ Narutowicza 11/12, 80-233 Gdansk, Poland
}

\begin{abstract}
The article analyses environmental and ecological criteria of selecting the most beneficial offer in the aspect of LCC. Construction works contracts and the potential method of defining the above criteria, among others, is pondered on (for example by the recommendation of a material, which is supposed to be used, a ban on substances that are harmful for human health as well for the environment). In the relation to the above, it is necessary to define technical parameters that have an impact on the environment, for example the level of pollution and noise emission, electricity and water consumption, or stating the minimal involvement of a processed ingredient. In addition the article presents also an account of the life cycle cost of a building from the point of view of environmental criteria constituting an element of selecting the most beneficial offer in the area of competitive tendering.
\end{abstract}

\section{Introduction}

One of the key priorities of the EU implemented under the Europe 2020 strategy is sustainable development involving the support of the competitive economy, efficiently utilizing resources and environmentally friendly. In many EU documents promoting sustainable development, as a basis for making investment decisions, is shown a method of estimating the life cycle costs (LCC - Life Cycle Cost) of a building. The life cycle cost is now widely applied in various fields of life, it is also the subject of numerous studies and research carried out on behalf of private companies and public institutions. The new approach involves the integration of environmental considerations in the design of buildings at an early stage, and carrying out their evaluation in respect of environmental impact (in terms of energy consumption, the possibility of limiting the consumption of new raw materials, extending the period of operation, reducing the amount of waste) in all phases of the life cycle.

Public procurements accounts for a significant share of the market, and their value in the individual EU Member Countries was in 2015 10-20\% of GDP [1]. The purpose of

*Corresponding author: beata.grzyl@,wilis.pg.gda.pl 
publicizing the environmentally-friendly public contracts, carried out on the basis of appropriate criteria, applicable to design, implementation and management of building structures, is to improve the environment by reducing the consumption of energy and natural resources, reducing $\mathrm{CO}_{2}$ emissions, increasing the use of energy produced from renewable sources, prevention of a climate change. Making procurements, which are taking into account environmental criteria in assessing life-cycle costs, contributes to lowering the cost of use and maintenance of buildings but it is also part of a long-term development strategy for the region based on innovative technologies.

\section{Building life cycle costs - the analysis and components}

According to the idea of sustainable development, at the design stage of a building there is a need to apply LCC analysis in order to optimize the cost of its life cycle, taking into account safety, degree of functional failure, frequency of making maintenance, etc. According to [1] 80-90\% of costs incurred in the course of implementation stage, use and maintenance of the facility is determined at the design stage. In practice, in many cases the costs incurred in the full life cycle, however, are omitted, and investment decisions are made based on short-term criteria. Such activities cause negative consequences of a financial but also environmental nature (e.g. arises a need for earlier disposal of the obtained waste). Due to the fact that the lifetime of certain objects reaches 30-50 (70) years, and the costs associated with their operation and maintenance far outweigh the initial expenses (Table 1), the criterion of the lowest price cannot be the sole determinant in making an investment decision [2].

Table 1. Groups of costs and their percentage share in the life cycle costs of a building.

\begin{tabular}{|c|c|c|}
\hline Stage & Cost share & Cost groups in terms of the scope of activities \\
\hline $\begin{array}{l}\text { Preparation } \\
\text { and } \\
\text { implementation }\end{array}$ & $20 \%$ & $\begin{array}{l}\text { - the concept and definition (including the cost of market } \\
\text { research, design and analysis, defining requirements for object) } \\
\text { - the design and development (including the costs of the } \\
\text { documentation design, software) } \\
\text { - the implementation (installation) of the object, installation of } \\
\text { equipment (including production costs and delivery on market } \\
\text { specific products and devices, environmental and social costs) }\end{array}$ \\
\hline $\begin{array}{c}\text { Use } \\
\text { and } \\
\text { maintenance }\end{array}$ & $75 \%$ & $\begin{array}{l}\text { - the use and handling (includes cost of repairs, maintenance, } \\
\text { troubleshooting, spare parts, technical support found during the } \\
\text { operation, the environmental and social costs) } \\
\text { - the liquidation (includes the cost of demolition, dismantling, } \\
\text { recycling and/or disposal, the environmental and social costs). }\end{array}$ \\
\hline Demolition & $5 \%$ & - liquidation, disposal, recycling \\
\hline
\end{tabular}

Source: own elaboration based on [3].

\subsection{LCC analysis procedure}

There are two main groups of methods of LCC analysis [4]:

- simple, uncomplicated serving for comparisons, allowing to select the optimal variant of the process without discounting,

- complex, including an analysis of discounted cash flows in the period of construction of the object to its demolition, integrating different elements of the costs obtained during the life cycle (including maintenance, operation, repair, inspection). 
The selection of the appropriate LCC method depends on the nature, scope and complexity of the project. The methods that can be used to estimate the components of the building object life cycle cost (or its elements) are [4]:

- the engineering method for estimating the cost (direct testing of the product, component after component)

- the method of estimating the cost by analogy (an estimate based on experience gained from similar products or technologies)

- the parametric method of estimating the cost (the use of parameters and variables to develop correlation of estimating the cost).

In the LCC analysis one should take into account the following assumptions:

- the considered costs should relate to the same period of use,

- the comparison of cost should be subjected to only those projects (or their elements) which provide the projected period of use, functional and useful requirements.

- the analyzed costs in the proposed period of use should include all expenses related to the usage (e.g. the media) and the maintenance of facility (renovation, repair, inspection, troubleshooting), as well as liquidation,

- in the cost calculation one should take into account the technique of discounting. Methods of preparing the full life-cycle costing is included in [5].

\subsection{Restrictions on the LCC analysis application}

Despite many advantages, in practice LCC analysis faces difficulties and constraints characteristic of many tools for calculating costs [1].

1. The LCC analysis method is not strict, so as a result it can generate different results. This is due to fact that the costs included in the analysis are only approximate values (especially those assigned to operation, maintenance and demolition phase), and additionally a large number of reliable input data are required but they are difficult to obtain (e.g. from the property managers).

2. There is no accurate model of aging buildings, taking into account the development of civilization and the resulting changes in the cost calculation. There is also great difficulty in estimating at the design stage environmental and social costs.

3. In practice, the observed lack of broad knowledge of designers on the saving technologies and the associated costs.

\section{The LCC analysis in public procurements}

The basic legal acts adopted at EU level, regulating the policy regarding public procurements are Directives [6] and [7].

Under the current provisions of the Public Procurement Law [8], the evaluation criteria are "price or cost" or "price or cost and other criteria related to the object of the contract" (including environmental issues - energy efficiency of the contract, innovative aspects).

The aim of inclusion into the tendering environmental requirements is to obtain contracts with the best value for money, taking into account environmental issues. The Contracting Authority may take into account environmental issues in subsequent stages of the procurement procedure, at the stage of:

- description of the contract,

- qualification of contractors,

- selection of the best offer,

- determination of the conditions for the agreement implementation. 


\subsection{The environmental criteria for selecting the best offer}

According to the Public Procurement Act being currently in force [9], in the description of the contract, the contracting authority may place requirements on the performance or functionality, including the environment, provided that the specified parameters are sufficiently precise to enable contractors to determine the purpose of the contract and the contracting authority giving the contract. In case of contracts for construction works, in the description of the contract, the contracting authority may require.: specific levels of impact on the environment and climate, specific packaging and labeling, use of specific processes and production methods at every stage of the object life cycle.

It should be noted, however, that the expectation by the customer to use too innovative solutions, may in practice result in the inability to implement the project because of too high offer prices.

The contracts for construction works in the public sector, including the cost of the life cycle and environmental criteria for selection of the best offer can be considered in a broad sense. These types of requirements, the implementation of a new object can be imposed on designers, contractors, subcontractors and managers. In the event when the subject of contract is the construction of a new facility or renovating an existing one, the contracting authority should examine the various options (providing at the same time in the tender documents the possibility of submission variant tenders), taking into account energy consumption and impact on the environment in terms of life cycle costs. The combination of such analyzes in the calculation of costs, i.e. the comparison of investment and long-term maintenance costs, just gives a complete picture of the total costs related to the acquisition, maintenance and use of the facility, it also allows for the indication of the most economically advantageous tender, which also provides high environmental efficiency.

By defining environmental criteria for public procurement, the contracting authority is obliged to apply the rules resulting from directives [6, 7].

1. The criteria may not give the contracting authority unrestricted freedom of choice, i.e. they must be formulated in such a way to allow all bidders to make their interpretation in the same way, they must provide an objective basis to differentiate offers.

2. The criteria must give the contracting authority the ability to verify the evidence, i.e. the orderer should clearly identify what evidence should present bidders within each criterion and how it will be judged.

3. The criteria should allow for an effective competition.

4. In the contract notice and contract documents, the contracting authority must specify the criteria that will be used to indicate the most economically advantageous tender and the relative weight, which he assign to each of them, in the form of a specific number or a range with an appropriate maximum spread, and sub-criteria to be applied and their weight.

Requirements for the best offer selection should vary depending on the scope of the future agreement. The subject of the contract may be a design object, the implementation of the object using "build" or "design and build" or "design, build and manage" investment methods.

\subsection{The analysis of evaluation criteria used in practice}

In order to determine how often in practice environmental criteria are applicable, the authors have analyzed 550 notices published in the Public Procurement Bulletin in the fourth quarter of 2016 by the contracting authorities operating in the province of Pomerania. The analysis allowed to draw up a statement of the most frequently used by the 
authorities evaluation criteria for construction works using "build" investment method / form. The results are presented in the Table 2.

Table 2. The frequency of use the criterion in tender procurement for works implemented in the form "build".

\begin{tabular}{|c|c|}
\hline Type of criterion & Frequency of criterion use the [\%] \\
\hline Price & 100 \\
\hline Period of quality guarantee & 92.4 \\
\hline term of the contract & 34.5 \\
\hline Date of payment & 6.7 \\
\hline Employees experience & 5.2 \\
\hline Environmental aspects & 0.6 \\
\hline Social aspects & 0.5 \\
\hline Technical parameters & 0.4 \\
\hline
\end{tabular}

Source: own data

The survey results indicate that the basic criterion for procurement is the price - it occurs in all analyzed procedures. Willingly used by the ordering authority criterion beyond price is warranty of quality $(92.4 \%)$, term of the contract $(34.5 \%)$, date of payment $(6.7 \%)$ and experience of employees (5.2\%). Other criteria (environmental, social, technical parameters) in practice are used very rarely. In each of the analyzed notices of procurement for works implemented in the form "build", the price criterion was in the importance of at least $60 \%$. In 324 procedures $(58.9 \%)$ occurred only 2 criteria. In none of the analyzed procedures were applied environmental criterion referred to the cost of the object life cycle.

\subsection{Examples of evaluation criteria of the tender for construction works carried out by using "design and build" form}

It is important to clearly define in the contract notice and tender documents, the expectations of the customer in meeting the environmental criteria. The ordering authority must determine the number of points giving for the fulfillment of each criterion. It is proposed that environmental award criteria were at least $15-20 \%$ of the total possible points. Such a mechanism will mobilize designers and contractors to present in the offers innovative ideas (e.g. in the field of design solutions, applied technologies and devices) reducing environmental impact. The ordering authority may just define his expectations (as a criterion for choosing the best offer) that their fulfillment assured to obtain better (i.e. lower, e.g. about 20-40\%) indicators of demand for energy, water, waste, and emissions to the atmosphere of harmful substances. The size of the expected indicators can be applied to the value of indicators specific for the reference object that meets the current technical conditions. This information may also be attributed to the cost of the life cycle of the object (specifying them in the amounts or percentages in relation to the object that meets the current regulations). The description of criteria together with the weights and method of evaluation of the offer are given in Table 3.

\subsection{The LCC example using cost impact on the environment}

The life-cycle cost of a building is the basis for making long-term investment decisions, but also has a significant impact to increase their environmental performance (lower energy consumption, lower $\mathrm{CO}_{2}$ emission). Increasing the initial capital costs typically results in lower running costs in the life cycle (Table 4) and an increase in the final value of the property. 
Table 3. The description of criteria which the ordering entity will apply in selecting a tender together with weights of the criteria and method oftenders evaluation ("design and build" variant).

\begin{tabular}{|c|c|c|c|}
\hline No. & Name of criterion & $\begin{array}{c}\begin{array}{c}\text { Weight } \\
\text { of } \\
\text { criterion }\end{array} \\
\end{array}$ & Method for assessing \\
\hline 1. & Price & $30 \%$ & $\begin{array}{c}\text { The offer price - up to } 30 \text { points } \\
\text { The criterion 'offer price' the highest number of points } \\
\text { will receive the offer with the lowest price (net). } \\
\text { The following formula is applied: } \\
\text { the number of points } \mathrm{C} 1=(\mathrm{Cmin} / \mathrm{Cbad}) \times 30 \\
\text { where: Cmin - the lowest price net of all respondent } \\
\text { tenders } \\
\text { Cbad - the net price stated in the examined offer }\end{array}$ \\
\hline 2. & $\begin{array}{l}\text { Compliance of } \\
\text { architectural concept } \\
\text { with } \\
\text { the requirements } \\
\text { and assumptions } \\
\text { contained in } \\
\text { PF-U and the Terms } \\
\text { of Reference }\end{array}$ & $30 \%$ & $\begin{array}{l}\text { The compatibility of the designed surface will be the } \\
\text { subject to the assessment, their layout and purpose of the } \\
\text { assumptions contained in the PF-U and the Terms of } \\
\text { Reference. } \\
\text { In the criterion 'the compatibility of the concept' the } \\
\text { highest number of points will receive the offer best } \\
\text { corresponding to the requirements contained in the PF-U } \\
\text { and the Terms of Reference. It will be applied the } \\
\text { formula: } \\
\text { number of points K2 = (Kodp / Kbad) } \times 30 \\
\text { where: Kodp - requirements mostly fulfilled of all } \\
\text { tenders } \\
\text { Kbad - the requirements contained in the examined offer }\end{array}$ \\
\hline 3. & $\begin{array}{l}\text { Environmental } \\
\text { aspects }\end{array}$ & $20 \%$ & $\begin{array}{l}\text { The energy consumption in the period of } 1 \text { year (weight } \\
\text { criterion of } 10 \% \text { ) and } \mathrm{CO} 2 \text { emissions in the period of } 1 \\
\text { year (weight criterion: } 10 \% \text { ) will be subjected to the } \\
\text { assessment. In the criterion of 'environmental aspects' } \\
\text { the contracting authority will award points according to } \\
\text { the following formula: } \\
\text { - the annual energy consumption/emissions of CO2 at } \\
\text { the maximum level (according to the Terms of } \\
\text { Reference - a reference to the reference building) - } 5 \\
\text { points for each criterion. } \\
\text { In the case to propose in the offer a better (lower) results } \\
\text { in comparison with the maximum values specified in the } \\
\text { Terms of Reference, there will be awarded points } \\
\text { (according to timetabled intervals) in proportion to the } \\
\text { improved performance - } 10 \text { points maximum for each } \\
\text { criterion. }\end{array}$ \\
\hline 4. & $\begin{array}{l}\text { Costs of life cycle } \\
\text { (assuming lifetime }= \\
30 \text { years, the } \\
\text { discount rate }=5 \% \\
\text { and the methodology } \\
\text { to the LCC analysis } \\
\text { specified in the } \\
\text { Terms of Reference) }\end{array}$ & $20 \%$ & $\begin{array}{l}\text { In the criterion of 'life cycle costs of building' most } \\
\text { points will receive the offer with the lowest cost. It will } \\
\text { be applied the formula: } \\
\text { the number of points } \mathrm{K} 4=(\mathrm{Kmin} / \mathrm{Kbad}) \times 20 \\
\text { where: Kmin - the cost of the lowest among all the } \\
\text { offers } \\
\text { Kbad - the cost specified in the examined offer }\end{array}$ \\
\hline
\end{tabular}

Source: own study based on [10]. 
Table 4. The comparative analysis of investment cost and other parameters for a public building, carried out in Poland in the standard and energy-saving technology.

\begin{tabular}{|c|c|c|c|}
\hline Description & Unit & $\begin{array}{c}\text { Building (reference) } \\
\text { in the standard } \\
\text { technology }\end{array}$ & $\begin{array}{c}\text { Building in the } \\
\text { energy-saving } \\
\text { technology }\end{array}$ \\
\hline Demand for electricity & $\mathrm{kWh} /$ year & 69474,00 & 45331,00 \\
\hline Demand for heat & $\mathrm{GJ} /$ year & 2719,00 & 184,00 \\
\hline $\begin{array}{c}\text { Cost of heating and hot water } \\
\text { (without lighting) }\end{array}$ & $\mathrm{PLN} /$ year & 210808,50 & 43002,00 \\
\hline The investment cost* & $\mathrm{PLN}$ & 42450000,00 & 44560000,00 \\
\hline Avoided CO $\mathrm{CO}_{2}$ emissions over 30 years & $\mathrm{Mg} /$ year & - & 9262 \\
\hline $\begin{array}{c}\text { Share of renewable energy in the } \\
\text { energy balance }\end{array}$ & $\%$ & - & 70,10 \\
\hline $\begin{array}{c}\text { Building energy standard (heating, } \\
\text { hot tap water, ventilation, air } \\
\text { conditioning) }\end{array}$ & $\begin{array}{c}\mathrm{kWh} /\left(\mathrm{m}^{2}\right. \\
\text { year) }\end{array}$ & $\sim 90,00$ & 19,24 \\
\hline Difference in investment costs & $\mathrm{PLN}$ & - & 2110000,00 \\
\hline $\begin{array}{c}\text { Simple payback period of additional } \\
\text { investment }\end{array}$ & years & - & 14,6 \\
\hline
\end{tabular}

Source: [11]

* Investment cost does not include lifetime, discount rate, expenses related to conducting the activities of repair, maintenance and troubleshooting, etc., demolition and disposal of materials.

Results of the analysis indicate that taking into account investment cost value and additional benefits of reducing $\mathrm{CO}_{2}$ emissions and share of energy from renewable sources in the energy balance, implementation of building in the energy-saving technology is better for the customer.

The energy costs in the course of the building use represent a substantial part of the total cost of ownership. The reduction of energy consumption is an effective solution both financially and environmentally. It is also important savings in terms of maintenance and replacement of equipment. It is worth considering a solution that provides an extended period of their exchange, as well as the selection of materials that reduce the frequency of carrying out maintenance operations, repair and overhaul. An important issue is the cost of object liquidation, including both the cost of removing and safe disposal of some materials.

\section{Conclusions}

The method of estimating the life cycle cost of a building is widely applied at the stage of decision-making in design, selection of technology, use or renovation. It also allows selection of the most cost-effective solution for planning and control of maintenance costs and use of the building. Analyzing a particular expense, taking into account the cost of acquisition, functionality maintenance, restoring the initial value and disposal, i.e. making a comprehensive analysis of the costs generated throughout the life cycle, it allows to determine the "real" value of the contract. Such approach should be applied, among others, by public authorities in the contracting process of construction works (in the variant "design and build" and "build") in order to maintain the highest efficiency of public spending.

Taking into account certain advantages of the analysis, it should be noted, however, that the life cycle cost of the building is a difficult issue for the widespread introduction and use in the area of public procurement, among others, due to the current practice, attitudes and habits of ordering authorities. The principal limitations in the broad application of environmental criteria to the public are:

- a small number of specific and clearly defined environmental criteria for the design and implementation stages of a work, 
- concerns of ordering authorities regarding the correctness of assessment being in compliance with environmental criteria at the stage of the submitted tenders examination,

- lack of clear standards (guidelines) of the life cycle cost calculating method of an environmentally friendly object; a large number of methodology and data may result in the inability to compare results,

- lack of specialists in the field of determining the life-cycle costs,

- lack of broad dissemination of the applied environmental criteria,

- low awareness of the benefits arising from the use of environmentally friendly buildings,

- lack of a broad government support for the implementation and promotion of environmental criteria for selection of the best offer.

\section{References}

1. http://gpp-proca.eu/pl/wp-content/uploads/sites/6/2014/12/Green-ProcA-GuidelinesGPP-in-SEAPs-PL.pdf

2. B. Grzyl, A. Kristowski, K. Jamroz, A. Gobis, Methods of estimating the cost of the traffic safety equipment life cycle Proceedings of GAMBIT (to be published)

3. http://ec.europa.eu/DocsRoom/documents/5058/attachments/1/translations/en/rendition s/pdfhttp://ec.europa.eu/environment/gpp/pdf/criteria/office_building_design/PL.pdf

4. PN-EN 63300-3-3 Zarzadzanie niezawodnościa część 3-3: Przewodnik zastosowań. Szacowanie kosztu cyklu życia (2006)

5. ISO 15686-5:2008 Buildings and constructed assets: Service - life planning. Part 5: Life-cycle costing

6. Dyrektywa Parlamentu Europejskiego i Rady 2014/24/UE z dn. 26 lutego 2014 r. w sprawie zamówień publicznych, uchylająca dyrektywę 2004/18/WE

7. Dyrektywa Parlamentu Europejskiego i Rady 2014/25/UE z dn. 26 lutego 2014 r. w sprawie udzielania zamówień przez podmioty działające w sektorach gospodarki wodnej, energetyki, transportu i usług pocztowych, uchylająca dyrektywę 2004/17/WE

8. https://www.uzp.gov.pl/_data/assets/pdf_file/0009/33102/UMl.pdf

9. Ustawa z dn. 22 czerwca 2016 r. o zmianie ustawy - Prawo zamówień publicznych oraz niektórych innych ustaw, Dz. U. z 2016, poz. 1020

10. Krajowa Agencja Poszanowania Energii S.A., Wytyczne realizacyjne dla budynku użyteczności publicznej w m. st. Warszawie, mające na celu zapewnienie optymalnego ekonomicznie poziomu wymagań dotyczących charakterystyki energetycznej budynku, B. Kacprzyk, Koszty cyklu życia - zastosowania praktyczne (w:) materiały konferencyjne, Dokumenty kosztowe $w$ procesie inwestycyjnym, Konferencja Stowarzyszenia Kosztorysantów Budowlanych, Warszawa 17-18.03.2016, p. 60 (2016)

11. Krajowa Agencja Poszanowania Energii S.A., A. Węglarz, M. Pierzchalski, D. Koc, Koszty w cyklu życia budynku (w:) materiały konferencyjne, Cena lub koszt cyklu $\dot{z} y c i a$. Nowe uwarunkowania $w$ zamówieniach publicznych na roboty budowlane, 22 Konferencja naukowo-techniczna, Ciechocinek 5-7.10.2016, p. 61 (2016) 